\title{
Polisakarida Baru Sacran Potensial Mempercepat Penyembuhan Luka
}

Nasrul Wathoni

Fakultas Farmasi Universitas Padjadjaran, Sumedang, Jawa Barat, Indonesia

Terbit online : 24 Juni 2016

\section{Abstrak :}

Sebuah polisakarida natural baru yang dinamai Sacran dan berasal dari algae (cyanobacterium) Aphanothece sacrum (Suizenji nori) memiliki berat molekul terbesar di dunia. Saat ini dipasaran Jepang telah beredar kosmetik yang mengandung sacran yang diklaim memiliki efek kelembaban atau moisturizing paling baik di dunia. Dengan berat molekul yang super tinggi, saat ini sacran memiliki karakteristik yang unik yang bisa digunakan dalam berbagai aplikasi terutama dalam bidang biomedik. Banu-baru ini telah dikembangkan sacran hidrogel film sebagai wound dressing atau penutup luka yang mampu meningkatkan tingkat penyembuhan luka serta lebih baik dibanding polisakarida alam yang saat ini digunakan dipasaran yakni Alginat.

Keyword : Polisakarida, sacran, Aphanothece sacrum

\section{Pendahuluan}

Sebuah polisakarida natural baru yang dinamai Sacran dan berasal dari algae (cyanobacterium) Aphanothece sacrum (Suizenji nori) memiliki berat molekul terbesar di dunia yakni $2.9 \times 10^{7} \mathrm{DA}$. Jauh lebih tinggi dari Aloeride, polisakarida dari Aloe Vera yang ditemukan pada 2001 sebesar $4 \times 10^{6} \mathrm{DA}$. Ataupun polisakarida Vitargo yang ditemukan pada 2013 yang hanya $303.5 \mathrm{kDA}$.

Sacran ditemukan pada tahun 2006 oleh Dr. Tatsuo Kaneko dari Japan Advanced Institute of Science and Technology. Sacran ini dapat diekstraksi dari "Suizenji nori" yang sebelumnya ditemukan pada tahun 1872 oleh Willem Frederik Reinier Suringar, seorang ahli botani dari Belanda di SuizenjiPark, Kumamoto, Jepang.

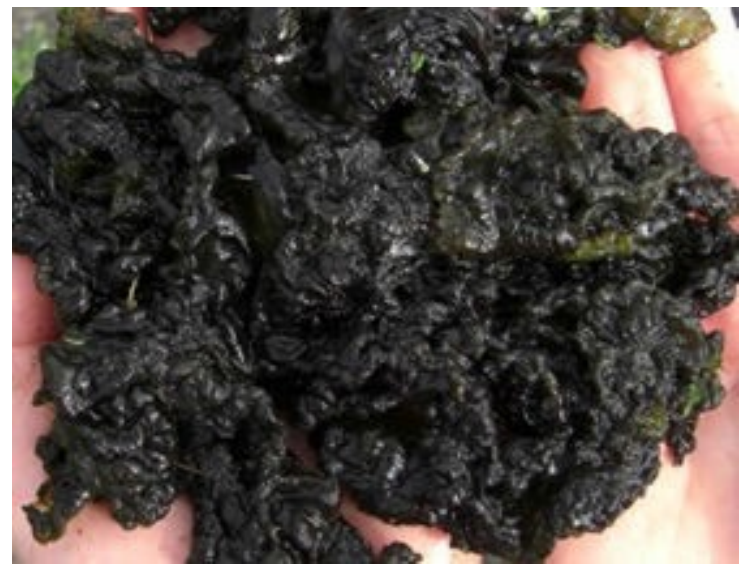

Gambar 1. Aphanothece sacrum (Suizenji nori) (pic: www.jaist.ac.jp) 
Dia terkesan dengan lingkungan yang indah di taman Suizenji oleh karenanya diberikan nama "Suizenji nori" untuk jenis algae ini. "Suizenji nori" telah digunakan sebagai makanan mewah di masakan Jepang, tapi di alam "Suizenji non" saat ini sangat langka dan terdaftar di Red Data Book (oleh Kementerian lingkungan Jepang) sebagai spesies yang terancam punah.

Dengan berat molekul yang super tinggi, saat ini sacran memiliki karakteristik yang unik yang bisa digunakan dalam berbagai aplikasi terutama dalam bidang biomedik. Diantaranya, sacran memiliki efek moisturizing yang tinggi, biomaterial yang aman, bisa membentuk hidrogel, bisa dibuat film, dan memiliki efek anti inflamasi.

\section{Characteristics of Sacran}

Super-macromolecule with molecular weight of about 20 million

Anionic polysaccharide with about $11 \%$ of sulfate groups and $12 \%$ of carboxyl groups per sugar chain

Eleven types of monosaccharides including glucose, galactose, xylose and fucose have been identified as components and sacran also contains a novel monosaccharide, sulfated muramic acid.

Aphanothece sacrum is a prokaryote but sacran is predicted to have a similar structure to mucopolysaccharides produced by eukaryotes and is anticipated to have a range of physiological activities.

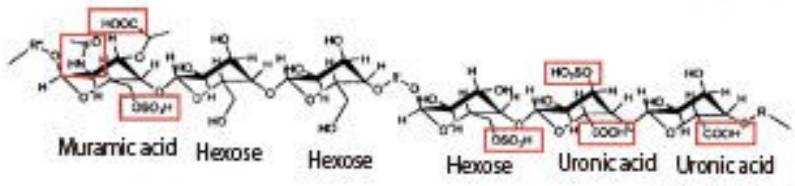

Part of sacran sugar residue sequence

\section{Gambar 1. Karakteristik Sacran (www.kokenmpc.co.jp)}

Saat ini dipasaran Jepang telah beredar kosmetik yang mengandung sacran yang diklaim memiliki efek kelembaban atau moisturizing paling baik di dunia.

Penelitian tentang sacran masih sangat sedikit dan terus dilakukan serta sangat potensial untuk dikembangkan sebagai kandidat imunostimulan, tissue enginering, pembawa nano bahkan mRNA. Hingga kini telah dibentuk komunitas peneliti sacran dan telah melakukan konferensi ilmiah internasional pertamanya tahun lalu.

Baru-baru ini telah dikembangkan sacran hidrogel film sebagai wound dressing atau penutup luka yang mampu meningkatkan tingkat penyembuhan luka serta lebih baik dibanding polisakarida alam yang saat ini digunakan dipasaran yakni Alginat. Penelitian ini telah dipublikasikan di International Journal of Biological Macromolecules yang telah online sejak Mei 2016.

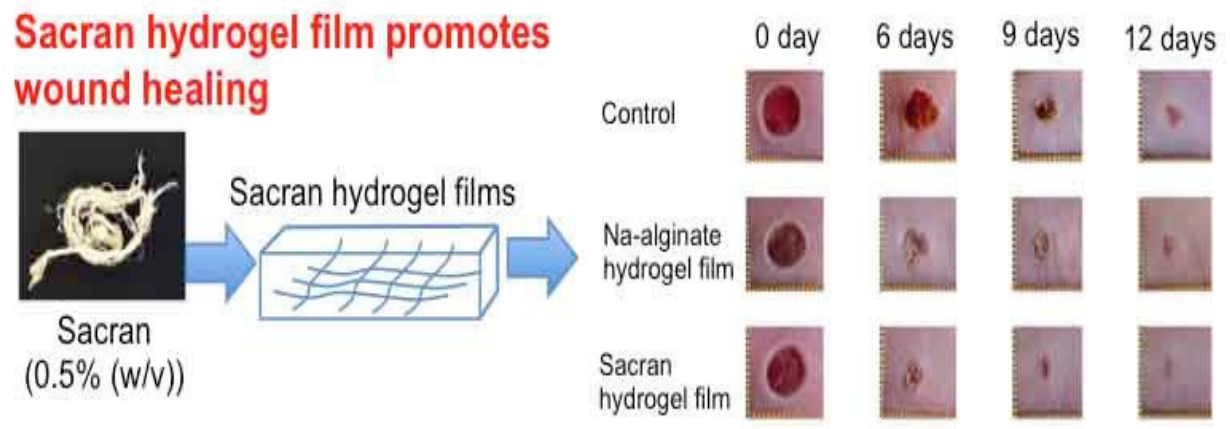

Gambar 3. Penelitian terbaru tentang sacran (IJBM, Volume 89, August 2016, Pages 465-470) 
Dari hasil karakterisasi di penelitian ini, ketebalan film hidrogel sacran ini lebih rendah dibanding dari natrium alginat (Na-alginat) Film. Analisis termal menunjukkan, sacran lebih stabil dibanding $\mathrm{Na}$-alginat karena memiliki suhu degradasi yang lebih tingi. Suhu degradasi yang tinggi erat kaitannya dengan berat molekul yang sangat tinggi yang mencapai 100,000 kali lebih besar di banding Na-alginat.

Selain itu, kemampuan absorbsi atau mengembang dari film hidrogel sacran dalam air pada 24 jam adalah 19 kali lipat dibandingkan dengan berat awalnya. Sementara itu, film hidrogel Naalginat tidak mampu mempertahankan bentuk filmnya setelah rehidrasi. Penelitian sebelumnya membuktikan bahwa sacran memiliki struktur Liquid Crystalline (LC) pada konsentrasi yang rendah sehingga mampu membentuk ikatan secara fisika melalui ikatan antar rantai sacran. Ikatan ini dimungkinkan sangat lemah pada Na-alginat sehingga mudah hancur.

Sacran sebagai biomaterial yang aman dibuktikan dengan tidak menunjukkan sitotoksisitas apapun pada sel NIH3T3, yang merupakan galur sel fibroblast. Penelitian di mencit khusus tanpa rambut menunjukkan bahwa kemampuan hidrasi kulit dari film hidrogel sacran secara signifikan meningkatkan kadar air pada kulit mencit dan terbukti mampu meningkatkan kemampuan penyembuhan luka dibandingkan dengan kontrol (tanpa pengobatan).

Hal ini terjadi dimungkinkan bukan hanya efek moisturing tetapi juga adanya kemampuan efek anti inflamasi dari sacran. Hasil penelitian ini menyimpulkan bahwa sacran potensial sebagai biomaterial dasar dalam film hidrogel untuk aplikasi penutup luka (wound dressing).

Daftar pustaka:

http://www.daitokasei.com/products/SACRAN201510.pdf, diakses 24 Juni 2016.

Nasrul Wathoni, Keiichi Motoyama, Taishi Higashi, Maiko Okajima, Tatsuo Kaneko, Hidetoshi Arima. Physically crosslinked-sacran hydrogel films for wound dressing application. International Journal of Biological Macromolecules, Volume 89, August 2016, Pages 465-470.

Pugh N, Ross SA, EISohly MA, Pasco DS. Characterization of Aloeride, a new high-molecularweight polysaccharide from Aloe vera with potent immunostimulatory activity. J Agric Food Chem. $2001 \mathrm{Feb} ; 49(2): 1030-4$.

Li-Min Hao, Jian-Chun Zhang, Ji-Ke Lu,You-Song Zhang and Tian-Yi Wu. Characterization of A New High-molecular-weight Polysaccharide for Application in High-energy Solid Beverages. Journal of Food Processing and Preservation. Volume 37, Issue 5, pages 644650, October 2013 